\title{
ФТОРСОДЕРЖАЩИЕ АЛКЕНЫ И АЦЕТИЛЕНЫ В СИНТЕЗЕ ПРАКТИЧЕСКИ ВАЖНЫХ СОЕДИНЕНИЙ
}

\section{В.Г. Ненайденко}

Московский государственный университет им. М.В.Ломоносова, Москва, Россия 119991, Россия, г. Москва ул. Ленинские Горы, д. 1.

DOI: 10.19163/MedChemRussia2021-2021-18

E-mail: nenajdenko@org.chem.msu.ru

Среди главных тенденций развития органической химии последних 20 лет можно отметить ключевую роль фторорганических соединений. Связано это с чрезвычайно высокой практической важностью фторсодержащих соединений. В настоящее время около $25 \%$ новых лекарств и более $30 \%$ веществ, применяемых в сельском хозяйстве (агрохимикатов) содержат в своем составе хотя бы один атом фтора. Введение фтора в целевую молекулу меняет такие важнейшие параметры молекулы, как липофильность, растворимость, связывание с рецепторами, метаболизм, проницаемость мембран, кислотноосновные характеристики, конформационные свойства соединений. Все эти уникальные качества используются как рабочий инструмент в создании новых лекарств и материалов. Фторсодержащие функционально замещённые алкены и ацетилены обладают значительным синтетическим потенциалом для построения сложных молекул с заданным положением атомов фтора и перфторалкильных групп.<smiles>FC(F)(F)c1nc2n(c1Br)CCCCC2</smiles><smiles>FC(F)(F)C1(C[Al])NCCC2=C1CCCCC2</smiles><smiles>[R]c1ccc2[nH]c(C(F)(F)F)c(Br)c2c1</smiles><smiles>[R2]NC(=CBr)C(F)(F)F</smiles><smiles></smiles><smiles>OC1(C(F)(F)F)OC(C(F)(F)F)=C([Al])CC1Br</smiles><smiles>C=C(C)C(C)C</smiles><smiles>[R2]NC(=O)Cc1c(F)c(F)c(N[R10])c(F)c1F</smiles><smiles>[R10]Nc1c(F)c(F)c2c(c1F)N([R1])C(=O)C2</smiles><smiles>[R]c1c(C(F)(F)F)nn([R])c1[Y10]</smiles><smiles>[R]c1cc2ccccc2nc1C(F)(F)F</smiles><smiles>CC1(C[Al])NCCN1</smiles> 